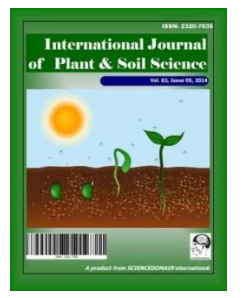

\title{
Soil Nutrient Dynamics and Yield of Cotton (Gossypium hirsutum L.) Following an Amendment with Cattle Manure
}

\author{
Otobong B. Iren ${ }^{1 *}$ and Yahya G. Aminu ${ }^{2}$ \\ ${ }^{1}$ Department of Soil Science, University of Calabar, Calabar, Cross River State, Nigeria. \\ ${ }^{2}$ Department of Crop Science, College of Agriculture, Jalingo, Taraba State, Nigeria.
}

\begin{abstract}
Authors' contributions
This work was carried out in collaboration between both authors. Author OBI designed the study and managed the analyses of the study. Author YGA wrote the first draft of the manuscript, managed the literature searches and did the statistical analysis. Both authors read and approved the final

manuscript.

Article Information

DOI: $10.9734 /$ IJPSS/2017/33124

Editor(s):

(1) Muhammad Shehzad, Department of Agronomy, Faculty of Agriculture, The University of Poonch Rawalakot, Pakistan.

Reviewers:

(1) Emine Karademir, Siirt University, Turkey.

(2) Adjolohoun Sébastien, University of Abomey-Calavi, Benin. Complete Peer review History: http://www.sciencedomain.org/review-history/19093
\end{abstract}

Original Research Article

Received $30^{\text {th }}$ March 2017

Accepted $26^{\text {th }}$ April 2017

Published 17 $7^{\text {th }}$ May 2017

\section{ABSTRACT}

The availability of cattle manure in the study area needs to be properly utilized to benefit the environment and provide nutrients to crop. A field experiment was conducted during the wet season (June-October) of 2014 planting season at two locations within the Research Farm of the College of Agriculture, Jalingo, Taraba State, Nigeria to determine the effects of cattle manure rates on soil nutrient distribution and yield of cotton. Four nitrogen rates in cattle manure (150, 200, 250 and 300 $\mathrm{kg} \mathrm{N} / \mathrm{ha}$ ) and a control (no amendment) were laid out in a randomized complete block design with three replications. The experimental soil was loamy sand whether at the surface $(0-15 \mathrm{~cm})$, subsurface $(15-30 \mathrm{~cm})$ or sub subsurface $(30-60 \mathrm{~cm})$ with clay content increasing down the profile. The soil $\mathrm{pH}$ was moderately acid at the surface but strongly acid at the sub surfaces. Nutrient distribution in the soil after cotton harvest shows that nutrients in the soil were affected by rates of application of cattle manure with the values increasing with increase in manure rates and decreasing as the soil depth increases. The yield components such as cottonseed yield, lint yield, seed yield, number of bolls per plant and boll weight were significantly $(P<0.05)$ improved 
compared with the control. The highest cottonseed yield of $1453 \mathrm{~kg} / \mathrm{ha}$ was produced from plots treated with $250 \mathrm{~kg} \mathrm{~N} / \mathrm{ha}$. Therefore, farmers are encouraged to use cattle manure in increasing the fertility level of soil as well as a way of safe agriculture with minimum pollution effects.

Keywords: Application rates; cattle manure; cotton; soil nutrient distribution; yield components.

\section{INTRODUCTION}

Cotton (Gossypium spp.) is a major fiber crop of global importance and has high commercial value. It has retained its Unique Fame and name as the "King of fibers" and "white gold" because of its higher economic value among cultivable crops for quite a long period $[1,2]$. Cotton is the most important natural source of fiber used in textile industry and also a valuable source of oil [3]. It is grown commercially in the temperate and tropical regions of more than 70 countries [2]. In Nigeria, the major production areas are Katsina, Kaduna, Sokoto, Kano, Bauchi, Borno, Taraba, Zamfara, Kebbi, Jigawa and Adamawa States [4]. The major feature of cotton production in Nigeria is that about $80 \%$ of total production is by peasant farmers under rain fed conditions with simple tools and animals drawn implements [4]. Unfortunately, total production remains far below the national requirement of the textile and the oil mills [4].

Nutrients are the second most important limiting factors of crop production, after water. The agronomic factors responsible for low yield of cotton are numerous among which inappropriate fertilizer management is considered the major one. Nitrogen is the most limiting essential plant nutrient in the world and it needs to be supplied in proper quantities and time. Nitrogen requirement of crops is usually more than those of $\mathrm{P}$ and $\mathrm{K}$ but yet $\mathrm{N}$ has higher losses, lower use efficiency and greater potential to pollute the environment [5]. There are several factors which affect plant use efficiency of added nitrogen. These factors include application rate and timing, cultivar and climatic conditions. Research has shown that $\mathrm{N}$ and $\mathrm{K}$ uptake efficiency was increased when $\mathrm{N}$ was applied in splits $[6,7]$. Without sufficient $\mathrm{N}$, deficiency symptoms in cotton include stunting, chlorosis, and fewer and smaller bolls $[8,9]$. Cotton being a deep-rooted crop (about 180- $200 \mathrm{~cm}$ ) removes large quantities of nutrients from the soil profile. In order to improve cotton yield there is need for proper management of its nutrients requirements for quality yield. One of the ways of managing the nutrient status of soils for more profitable yield is by additional nutrient supply through the use of inorganic or organic fertilizers. Inorganic nutrient inputs are often too expensive for lowresource endowed farmers. Apart from this, they have been a threat to the environment resulting from indiscriminate use of inorganic fertilizers in intensive production system which has deteriorated the soil fertility and productivity. Organic nutrient inputs provide growth-regulating substances and improve the physical, chemical and microbial properties of the soil $[10,11,12]$. Application of broiler litter to cotton field in China increases soil nutrient concentrations as well as enhancing yields [13].

Cattle's rearing in Nigeria generates enormous amounts of litter that are generally perceived as hazard in the environment. Cattle dung is readily available and of no use to the herdsmen, it could be utilized more effectively and sustainably as manure. Cattle manure has been reported to be a potential source of organic matter and plant nutrients [14]. Therefore, the abundance of cattle manure in the study area had necessitated a research in its use in cotton field to ascertain the best rate of application for increase soil fertility. The objectives of this study were to investigate the influence of different rates of cattle manure on nutrient availability and distribution in cotton field as well as cotton yield.

\section{MATERIALS AND METHODS}

\subsection{Experimental Site}

The field experiment was conducted during the wet season (June-October) of 2014 planting season at two locations (Site $A$ and $B$ ) within the Research Farm of the College of Agriculture, Jalingo, Taraba State. The experimental site had been continuously used for maize crop production for over five years without any fertilizer application. Jalingo Local Government Area as is presently constituted, lies between longitude $11^{\circ} 09^{\prime}$ and $11^{\circ} 30^{\prime}$ east and between latitude $8^{\circ} 17^{\prime}$ and $9^{\circ} 01^{\prime}$ North. It lies in the Northern guinea savannah region of Nigeria [15]. Basement complex rock underlies the geology of Jalingo Local Government Area. 


\subsection{Land Preparation, Experimental Design and Treatments}

The experimental site was manually cleared and stumps were removed. Plots measuring $2 \mathrm{~m} \times 2$ $\mathrm{m}$ were made using traditional hoe. An alley of 2 $\mathrm{m}$ was left between blocks and $1 \mathrm{~m}$ between plots. The experiment was laid out in a randomized complete block design with three replications. The experiment comprised of four rates of cattle manure $(150,200,250,300 \mathrm{~kg}$ $\mathrm{N} / \mathrm{ha}$ ) and a control (no amendment). The various rates of cattle manure were calculated based on the nitrogen $(\mathrm{N})$ content in cattle manure and applied in dry form two weeks before planting using broadcasting with incorporation method.

\subsection{Planting and Field Maintenance}

Cotton (Jalingo local) seeds were sown on a well-prepared moist seed bed at a planting distance of $80 \mathrm{~cm} \times 40 \mathrm{~cm}$. Three seeds were sown per hole and were later thinned to one vigorous plant per stand. Weeding was done manually at 14,50 and 90 days after planting (DAP).

\subsection{Determination of Yield Components of Cotton}

Ten plants from the central rows were selected and tagged for the determination of cottonseed yield, seed yield, lint yield, number of bolls per plant and boll weight of cotton at harvest as follows:

\subsubsection{Cottonseed yield}

Cottonseed is the un-ginned cotton with seed and lint still attached. Cottonseed is the seed of the cotton plant that are surrounded by fibres which grow from the surface of the seed i.e. the seed with the lint still attached. This was determined after the remains of the reproductive part were removed and the cottonseed weighed using weighing balance.

\subsubsection{Seed yield}

This was determined after picking and delinting cottonseed from each plot.

\subsubsection{Lint yield}

This was obtained from each plot after the seeds were separated from the lint. Fibers grow from the seed coat to form a boll of cotton lint.

\subsubsection{Number of bolls/plant}

The boll is a protective fruit and was obtained by counting the number of bolls per plant.

\subsubsection{Boll weight}

The boll weight was determined by picking the boll from the tagged plants from each plot and weighed.

\subsection{Soil Sample Collection and Processing}

Composite soil samples were collected before treatment application at $0-15 \mathrm{~cm}, 15-30 \mathrm{~cm}$ and $30-60 \mathrm{~cm}$ soil depths for laboratory analysis. After experiment, composite soil samples were taken per treatment at $0-15 \mathrm{~cm}, 15-30 \mathrm{~cm}$ and 30-60 cm depths for post-harvest analysis to determine nutrient availability and distribution in the soil profile of the cotton field. The soil samples collected were properly bagged and labeled. Thereafter, the samples were air- dried, ground and sieved using a $2 \mathrm{~mm}$ sieve before analysis.

\subsection{Laboratory Studies}

The cattle manure and soil samples were analyzed in the laboratory using standard procedures as outlined by [16]. Particle size distribution was determined by the Bouyoucous hydrometer method, using sodium hexametaphosphate as a dispersant. Soil $\mathrm{pH}$ was determined in 1:2.5 soil: water ratio with a $\mathrm{pH}$ meter. Organic carbon was determined by Walkley Black Dichromate Oxidation Method. Total nitrogen $(\mathrm{N})$ was determined by the microkjeldahl method. Available phosphorus $(P)$ was extracted by the Bray 1 extraction method, and the content of $P$ was determined colorimetrically using a Technico AAll auto analyser (Technico, Oakland, Calif). Exchangeable bases (K, Na, $\mathrm{Ca}$, and $\mathrm{Mg}$ ) were extracted with $0.1 \mathrm{~N}$ ammonium acetate, $\mathrm{K}$ and $\mathrm{Na}$ were read with a flame photometer while $\mathrm{Ca}$ and $\mathrm{Mg}$ were determined through the EDTA titration method. Exchangeable acidity was determined by leaching the soils with $1 \mathrm{~N} \mathrm{KCl}$ and titrating aliquots with $0.01 \mathrm{NaOH}$. Effective cation exchange capacity (ECEC) was calculated as the sum of $\mathrm{Ca}, \mathrm{Mg}, \mathrm{K}$ and $\mathrm{Na}$ and exchangeable acidity. Base saturation was calculated by dividing the sum of exchangeable bases by ECEC and multiplying by 100 . 


\subsection{Statistical Analysis}

The data were subjected to statistical analysis using analysis of variance technique and LSD (Least Significant Difference Test) at the $5 \%$ level of probability to compare the superiority of treatment means using StatView Software.

\section{RESULTS}

\subsection{Properties of Soil and Manure Used for the Experiment}

The properties of the soil used for the experiment from the two locations were similar, the soil textural class was loamy sand whether at the surface $(0-15 \mathrm{~cm})$, subsurface $(15-30 \mathrm{~cm})$ or sub subsurface $(30-60 \mathrm{~cm})$ with clay content increasing down the profile in both locations (Table 1). The soil reaction $(\mathrm{pH})$ was moderately acid at the surface but strongly acid at the 15-30 $\mathrm{cm}$ and $30-60 \mathrm{~cm}$ sub surfaces. The $\mathrm{pH}$ values were below the optimum $\mathrm{pH}$ range of 5.8 to 6.5 given by [3] for cotton. However, [17] stated that cotton is not actually sensitive to soil reaction that it can be grown on a variety of soils with $\mathrm{pH}$ ranging from 5 to 8 and above as it is generally considered to be fairly tolerant to salinity.

The soil was very low in organic carbon, organic matter and total nitrogen $(\mathrm{N})$ contents and the values decreased with depth, which is typical of arable lands in the Northern savannah zone as crop residues are usually used up by livestock after harvest, leaving limited or no material on the surface for decomposition. Furthermore, the low organic matter (organic carbon) is also attributed to bush burning, long dry season and intensive mineralization during the rainy season [18]. The low $\mathrm{N}$ level observed in the soil could also be attributed to continuous cropping without additional nutrient supply.

The soil available phosphorus $(P)$ was medium at $0-15 \mathrm{~cm}$ and $15-30 \mathrm{~cm}$ soil depths, but low at the 30-60 cm soil depth. Exchangeable calcium (Ca), magnesium $(\mathrm{Mg})$, potassium $(\mathrm{K})$ and sodium (Na) contents were low. Based on [19] ratings, soils with values less than $5 \mathrm{cmol} / \mathrm{kg}, 1 \mathrm{cmol} / \mathrm{kg}$, $0.3 \mathrm{cmol} / \mathrm{kg}$ and $0.3 \mathrm{cmol} / \mathrm{kg}$ as low in $\mathrm{Ca}, \mathrm{Mg}, \mathrm{K}$ and $\mathrm{Na}$ respectively, for tropical soils. The low values obtained for organic matter, total $\mathrm{N}$, and exchangeable cations have also been reported by several researchers $[19,20]$ for soils in Northern Savannah zone of Nigeria.

Exchangeable acidity and effective cation exchange capacity (ECEC) of the soil were low. Soils with ECEC range of $5.0-15 \mathrm{cmol} / \mathrm{kg}$ are rated low for tropical soil [19]. However, the base saturation values obtained at the surface, subsurface and sub subsurface were high. This high percentage of base saturation values have also been reported by other researchers [19, 20] for soils of Northern Savannah zone of Nigeria.

Table 2 presents the nutrient composition of cattle manure used for the study. Cattle manure used had slightly alkaline $(7.56)$ reaction and $19.65 \%$ organic carbon, $0.98 \% \mathrm{~N}, 0.13 \% \mathrm{P}$, $0.50 \% \mathrm{~K}$ with $\mathrm{C}$ : $\mathrm{N}$ ratio of 20.05 revealing its ability to decompose slowly.

\subsection{Effect of Cattle Manure Rates on Soil Chemical Properties Distribution in the Soil Profile after Cotton Harvest}

Table 3 presents the nutrient availability and distribution in the soil profile after cotton harvest. Soil $\mathrm{pH}$ was moderately acid in reaction at all depths after cotton harvest in treated plots as against the strongly acid reaction obtained before experiment and the control plots. The values were raised from the initial values of 5.64, 5.37 and 5.12 for Site $A$ and 5.71, 5.39 and 5.22 for Site B to values ranging from 6.52-6.78, 6.456.58 , and 6.35-6.42 in the surface, subsurface and sub subsurface respectively after cotton harvest. The soil $\mathrm{pH}$ values generally increased with increasing manure rates and decreased with increasing soil depth.

The soil organic carbon and total nitrogen contents after cotton harvest were still very low but there were increases when compared with the initial values obtained before experiment and control. The values also increased with increasing manure rates and decreases with depth.

Application of cattle manure increased the soil available $P$ compared to the control. The available $P$ contents of the soil increases as the rate of application of cattle manure increased and decreases with depth. However, there was a reduction in available $P$ content after cotton harvest when compared with the values obtained before experiment. 
Iren and Aminu; IJPSS, 16(2): 1-10, 2017; Article no.IJPSS.33124

Table 1. Properties of the experimental soil before experiment

\begin{tabular}{|c|c|c|c|c|c|c|c|c|c|c|c|c|c|c|c|c|}
\hline \multirow{2}{*}{$\begin{array}{l}\text { Soil } \\
\text { depth } \\
\text { (cm) }\end{array}$} & \multicolumn{3}{|c|}{ Particle size (\%) } & \multirow[t]{2}{*}{ Texture } & \multirow{2}{*}{$\begin{array}{l}\mathrm{pH} \\
\left(\mathrm{H}_{2} \mathrm{O}\right)\end{array}$} & \multirow{2}{*}{$\begin{array}{l}\text { Org. C } \\
(\%)\end{array}$} & \multirow{2}{*}{$\begin{array}{l}\text { Org. M } \\
(\%)\end{array}$} & \multirow{2}{*}{$\begin{array}{l}\text { Total N } \\
(\%)\end{array}$} & \multirow{2}{*}{$\begin{array}{l}\text { Av. P } \\
\text { (mg/kg) }\end{array}$} & \multicolumn{4}{|c|}{ Exch. cations (cmol/kg) } & \multirow{2}{*}{$\begin{array}{l}\text { Exch. } \\
\text { Acidity } \\
\text { (cmol/kg) }\end{array}$} & \multirow{2}{*}{$\begin{array}{l}\text { ECEC } \\
(\mathrm{cmol} / \mathrm{kg})\end{array}$} & \multirow[t]{2}{*}{ BS (\%) } \\
\hline & Sand & Silt & Clay & & & & & & & $\mathrm{Ca}$ & Mg & $\mathrm{K}$ & $\mathrm{Na}$ & & & \\
\hline \multicolumn{17}{|l|}{ Site A } \\
\hline $0-15$ & 78.3 & 14.7 & 7.0 & LS & 5.64 & 0.28 & 0.48 & 0.02 & 8.50 & 2.0 & 1.4 & 0.20 & 0.15 & 0.60 & 4.35 & 86.21 \\
\hline $15-30$ & 78.3 & 10.7 & 11.0 & LS & 5.37 & 0.22 & 0.38 & 0.01 & 8.12 & 2.0 & 1.0 & 0.13 & 0.12 & 0.70 & 3.95 & 82.28 \\
\hline $30-60$ & 73.3 & 12.7 & 14.0 & LS & 5.12 & 0.10 & 0.17 & 0.01 & 7.00 & 3.2 & 0.4 & 0.20 & 0.15 & 0.70 & 4.65 & 84.95 \\
\hline \multicolumn{17}{|l|}{ Site B } \\
\hline $0-15$ & 77.6 & 13.4 & 9.0 & LS & 5.71 & 0.27 & 0.49 & 0.03 & 8.34 & 1.9 & 1.5 & 0.19 & 0.14 & 0.50 & 4.23 & 88.17 \\
\hline $15-30$ & 78.3 & 13.2 & 8.5 & LS & 5.39 & 0.23 & 0.33 & 0.01 & 8.12 & 1.9 & 1.2 & 0.14 & 0.12 & 0.60 & 3.96 & 84.84 \\
\hline $30-60$ & 81.3 & 10.7 & 8.0 & LS & 5.22 & 0.12 & 0.20 & 0.01 & 7.56 & 1.7 & 1.0 & 0.14 & 0.12 & 0.60 & 3.56 & 83.14 \\
\hline
\end{tabular}


Application of cattle manure increased the exchangeable $\mathrm{Ca}$ contents of the soil when compared to the initial values obtained before experiment and the control with the values increasing as the application rate increases and decreases with increasing soil depth. There was reduction in soil Mg contents after cotton harvest when compared with the initial values before experiment. The soil Mg contents increases also as the application rate increases and decreases down the soil profile. Similar trend was observed for soil $\mathrm{K}$ while the distribution of soil $\mathrm{Na}$ varied down the profile. Exchangeable acidity on the other hand decreases as the rate of application of cattle manure increases with the control plot recording the highest values. The effective cation exchange capacity (ECEC) of the soil and base saturation increased as the rate of application of cattle manure increased and decreased with depth.

Table 2. Nutrient composition of the cattle manure used

\begin{tabular}{ll}
\hline Parameter & Value \\
\hline $\mathrm{pH}\left(\mathrm{H}_{2} \mathrm{O}\right)$ & 7.68 \\
Organic matter (\%) & 33.88 \\
Organic carbon (\%) & 19.65 \\
Total nitrogen (\%) & 0.98 \\
$\mathrm{C}: \mathrm{N}$ ratio & 20.05 \\
Total phosphorus (\%) & 0.13 \\
Total potassium (\%) & 0.50 \\
Calcium (\%) & 0.88 \\
Magnesium (\%) & 0.48 \\
Sodium (\%) & 0.33 \\
\hline
\end{tabular}

\subsection{Effect of Cattle Manure Rates on the Yield Components of Cotton}

\subsubsection{Cottonseed yield}

Cottonseed is the un-ginned cotton with seed and lint still attached. The effect of rates of application of cattle manure on cottonseed yield was significant $(P \leq 0.05)$ when compared with control (Table 4). The highest yield of $1453 \mathrm{~kg} / \mathrm{ha}$ was produced from plots treated with $250 \mathrm{~kg}$ $\mathrm{N} /$ ha closely followed by plots treated with 200 $\mathrm{kg} \mathrm{N} / \mathrm{ha}(1427 \mathrm{~kg} / \mathrm{ha})$ while the control plots produced the least cottonseed yield of $369 \mathrm{~kg} / \mathrm{ha}$.

\subsubsection{Lint vield}

The effect of rates of application of cattle manure on the lint yield of cotton per hectare was significant $(P \leq 0.05)$ with plots treated with 250 $\mathrm{kg} \mathrm{N} /$ ha producing the highest lint yield (668.23 $\mathrm{kg} / \mathrm{ha}$ ) relative to other rates of application and control (Table 4). This was closely followed by plots treated with $200 \mathrm{~kg} \mathrm{~N} / \mathrm{ha}$ of cattle manure $(575.59 \mathrm{~kg} / \mathrm{ha})$. The least lint yield of cotton $(145.88 \mathrm{~kg} / \mathrm{ha})$ was obtained in the control plot.

\subsubsection{Seed yield}

Application of different rates of cattle manure significantly $(P \leq 0.05)$ increased the seed yield of cotton when compared with control (Table 4). Plots treated with $250 \mathrm{~kg} \mathrm{~N} / \mathrm{ha}$ produced the highest seed yield $(832.08 \mathrm{~kg} / \mathrm{ha})$ relative to other rates of application. This was closely followed by plots treated with $200 \mathrm{~kg} \mathrm{~N} / \mathrm{ha}$ $(787.09 \mathrm{~kg} / \mathrm{ha})$ while the least seed yield of cotton was obtained in the control plot (203.26 $\mathrm{kg} / \mathrm{ha})$.

\subsubsection{Number of bolls per plant}

Application of different rates of cattle manure significantly $(P \leq 0.05)$ increased the number of bolls per plant when compared with control (Table 4). The highest number of boll per plant (29) was obtained from plots treated with $250 \mathrm{~kg}$ $\mathrm{N} / \mathrm{ha}$ of cattle manure followed by plots treated with $200 \mathrm{~kg} \mathrm{~N} / \mathrm{ha}$ (28) while the least number of bolls per plant was from the control (15).

\subsubsection{Boll weight}

There were significant differences in boll weight among plants treated with various rates of cattle manure (Table 4). It was observed that plants treated with $250 \mathrm{~kg} \mathrm{~N} / \mathrm{ha}$ produced the largest cotton boll weight of $6.57 \mathrm{~g} / \mathrm{boll}$ followed plots treated with $300 \mathrm{~kg} \mathrm{~N} / \mathrm{ha}(6.27 \mathrm{~g} / \mathrm{boll})$ while lowest weight of $2.62 \mathrm{~g} / \mathrm{boll}$ was from the control plot.

\section{DISCUSSION}

The increase in soil $\mathrm{pH}$ as a result of the different rates of cattle manure applied may be attributed to the exchangeable cations present in the cattle manure. This confirms the findings of [12,21-24] who reported that manures have the ability to increase soil $\mathrm{pH}$.

The increase in soil organic carbon and total nitrogen contents obtained in this study is in line with the findings of [13] who reported increase in the soil organic carbon and total nitrogen contents in cotton field with increasing broiler litter rates and a decrease with increasing soil depth on upland silt loam soil. The decrease in the soil available $\mathrm{P}$ may be due to its uptake by the cotton plant and also by the activities of soil microbes in breaking down the manure during decomposition. 
Iren and Aminu; IJPSS, 16(2): 1-10, 2017; Article no.IJPSS.33124

Table 3. Soil nutrient availability and distribution following an amendment with different $\mathbf{N}$ rates in cattle manure

\begin{tabular}{|c|c|c|c|c|c|c|c|c|c|c|c|c|}
\hline \multirow{2}{*}{$\begin{array}{l}\text { Treatments } \\
\text { (kg N/ha) }\end{array}$} & \multirow{2}{*}{$\begin{array}{l}\mathrm{pH} \\
\left(\mathrm{H}_{2} \mathrm{O}\right)\end{array}$} & \multirow[t]{2}{*}{ Org. C (\%) } & \multirow[t]{2}{*}{ Org. M (\%) } & \multirow[t]{2}{*}{ Total N (\%) } & \multirow{2}{*}{$\begin{array}{l}\text { Av. P } \\
\text { (mg/kg) }\end{array}$} & \multicolumn{4}{|c|}{ Exchangeable cations (cmol/kg) } & \multirow{2}{*}{$\begin{array}{l}\text { Exch. A } \\
\text { (cmol/kg) }\end{array}$} & \multirow[t]{2}{*}{ ECEC (cmol/kg) } & \multirow[t]{2}{*}{ BS (\%) } \\
\hline & & & & & & $\mathbf{C a}$ & Mg & $\mathbf{K}$ & $\mathrm{Na}$ & & & \\
\hline \multicolumn{13}{|c|}{$0-15 \mathrm{~cm}$} \\
\hline Control & 5.46 & 0.20 & 0.35 & 0.03 & 5.42 & 2.14 & 0.50 & 0.21 & 0.10 & 0.93 & 3.88 & 76.03 \\
\hline 150 & 6.52 & 0.30 & 0.52 & 0.04 & 6.27 & 2.44 & 0.64 & 0.27 & 0.11 & 0.63 & 4.09 & 84.60 \\
\hline 200 & 6.55 & 0.39 & 0.67 & 0.05 & 6.73 & 2.46 & 0.60 & 0.32 & 0.13 & 0.60 & 4.11 & 85.40 \\
\hline 250 & 6.69 & 0.42 & 0.72 & 0.07 & 7.68 & 2.56 & 0.70 & 0.35 & 0.11 & 0.61 & 4.33 & 85.91 \\
\hline 300 & 6.78 & 0.47 & 0.81 & 0.08 & 8.09 & 2.61 & 0.70 & 0.40 & 0.14 & 0.56 & 4.41 & 87.30 \\
\hline \multicolumn{13}{|c|}{$15-30 \mathrm{~cm}$} \\
\hline Control & 5.44 & 0.22 & 0.38 & 0.02 & 4.80 & 2.13 & 0.27 & 0.20 & 0.17 & 0.77 & 3.54 & 78.25 \\
\hline 150 & 6.45 & 0.26 & 0.45 & 0.04 & 5.50 & 2.20 & 0.56 & 0.24 & 0.18 & 0.71 & 3.89 & 81.75 \\
\hline 200 & 6.49 & 0.30 & 0.52 & 0.04 & 5.50 & 2.26 & 0.56 & 0.29 & 0.18 & 0.61 & 3.90 & 84.36 \\
\hline 250 & 6.52 & 0.30 & 0.52 & 0.05 & 5.90 & 2.36 & 0.63 & 0.29 & 0.18 & 0.63 & 4.09 & 84.60 \\
\hline 300 & 6.58 & 0.36 & 0.62 & 0.05 & 5.80 & 2.33 & 0.53 & 0.31 & 0.18 & 0.57 & 3.92 & 85.46 \\
\hline \multicolumn{13}{|c|}{$30-60 \mathrm{~cm}$} \\
\hline Control & 5.24 & 0.16 & 0.28 & 0.01 & 4.02 & 2.05 & 0.20 & 0.16 & 0.16 & 0.70 & 3.27 & 78.59 \\
\hline 150 & 6.35 & 0.23 & 0.40 & 0.03 & 4.30 & 1.93 & 0.43 & 0.15 & 0.13 & 0.63 & 3.27 & 80.73 \\
\hline 200 & 6.38 & 0.26 & 0.45 & 0.03 & 4.55 & 1.85 & 0.36 & 0.15 & 0.20 & 0.60 & 3.16 & 81.01 \\
\hline 250 & 6.39 & 0.28 & 0.48 & 0.03 & 4.45 & 1.85 & 0.53 & 0.17 & 0.13 & 0.62 & 3.30 & 81.21 \\
\hline 300 & 6.42 & 0.26 & 0.45 & 0.04 & 4.59 & 2.07 & 0.49 & 0.17 & 0.43 & 0.60 & 3.76 & 84.04 \\
\hline
\end{tabular}


Table 4. Effect of the application of different $\mathbf{N}$ rates in cattle manure on yield components of cotton

\begin{tabular}{llllll}
\hline $\begin{array}{l}\text { Cattle manure } \\
\text { rates (kg N/ha) }\end{array}$ & $\begin{array}{l}\text { Cottonseed yield } \\
\text { (seed with lint) } \\
\text { (kg/ha) }\end{array}$ & $\begin{array}{l}\text { Lint yield } \\
\text { (kg/ha) }\end{array}$ & $\begin{array}{l}\text { Seed yield } \\
\text { (kg/ha) }\end{array}$ & $\begin{array}{l}\text { Number of } \\
\text { bolls/plant }\end{array}$ & $\begin{array}{l}\text { Boll } \\
\text { weight } \\
\text { (g/boll) }\end{array}$ \\
\hline Control & 369 & 145.88 & 203.26 & 15 & 2.62 \\
150 & 1171 & 558.96 & 751.47 & 23 & 5.88 \\
200 & 1427 & 575.59 & 787.09 & 28 & 6.07 \\
250 & 1453 & 668.23 & 832.08 & 29 & 6.57 \\
300 & 1411 & 569.81 & 777.94 & 26 & 6.27 \\
LSD $(0.05)$ & 0.17 & 0.12 & 0.27 & 0.65 & 0.26 \\
\hline
\end{tabular}

The significant increase in cottonseed yield obtained in this study is in line with the findings of [25] who reported that organic manures had a positive effect on cottonseed yield. Similar reports were also observed by [26], that application of poultry manure significantly increased cottonseed yield. However, the highest cottonseed yield of $1453 \mathrm{~kg} / \mathrm{ha}$ obtained from plants treated with $250 \mathrm{~kg} \mathrm{~N} / \mathrm{ha}$ in this study was lower than the yield of $3543 \mathrm{~kg} / \mathrm{ha}$ obtained from cotton plants treated with $100 \% \mathrm{~N}$ from urea by [27] in Bangladesh but falls within the yield of $1559 \mathrm{~kg} / \mathrm{ha}$ and $1135.7 \mathrm{~kg} / \mathrm{ha}$ obtained by [5] during 2011 and 2012 planting seasons respectively, in Pakistan by using ten split application of $\mathrm{N}$ at each irrigation. The disparity in yield could be as a result of the inorganic $\mathrm{N}$ which is already in mineralized form hence fast release of nutrients or as a result of the prevailing climatic conditions in each location.

The yield components such as number of boll per plant and boll weight strongly influence the cottonseed yield [5]. The high lint and seed yields obtained in this study is in agreement with that of [28] who reported that lint and seed yields per boll were relatively higher under the application of poultry manure. In this study, seed yield increased relatively more than the lint yield contradicting [28] report that lint yield increased relatively more than seed yield.

Application of organic manure showed a significant effect on the size of cotton boll. This result is in line with that of [29] who reported larger boll size in poultry manure amended soil compared with non- applied plot. Larger boll produced more lint's and seed than the small size boll. Similar results have been reported by $[28,30]$ on cotton lint yield. The highest boll weight of $6.57 \mathrm{~g}$ obtained in this study is close to and even higher than the boll weight of $5.3 \mathrm{~g}$ obtained by [27] from using 100\% $\mathrm{N}$ from urea, and boll weight of $4.75 \mathrm{~g}$ obtained by [31] in India during summer cultivation of cotton. However, [5] recorded boll weight of 2.9 and $2.91 \mathrm{~g}$ with split $\mathrm{N}$ application during year 2011 and 2012, respectively which is almost like the boll weight $(2.62 \mathrm{~g})$ obtained in this study when no amendment was applied.

\section{CONCLUSION}

To sustain cotton production in Nigeria, incorporation of organic manure is utmost necessary. In this regard, the application of cattle manure as an organic source of $\mathrm{N}$ is found to be useful. In our study, we observed that the application of cattle manure will improve soil properties and cotton yield. Nutrient distribution in the soil after cotton harvest shows that nutrients in the soil were affected by rates of application of cattle manure with the values increasing with increase in manure rates and decreasing as the soil depth increases. The yield components such as cottonseed yield, lint yield, seed yield, number of bolls per plant and boll weight were significantly $(P<0.05)$ improved compared with the control. The highest cottonseed yield of $1453 \mathrm{~kg} / \mathrm{ha}$ was produced from plots treated with $250 \mathrm{~kg} \mathrm{~N} / \mathrm{ha}$. Therefore, farmers are encouraged to use cattle manure in increasing the fertility level of soil as well as a way of safe agriculture with minimum pollution effects.

\section{COMPETING INTERESTS}

Authors have declared that no competing interests exist.

\section{REFERENCES}

1. Reddy KC, Malik RK, Reddy SS, Nyakatawa EZ. Cotton growth and yield response to nitrogen applied through fresh and composted poultry litter. Cotton Science. 2007;11:26-34. 
2. Saleem MF, Bilai MF, Awais M, Shahid $M Q$, Anjum SA. Effect of nitrogen on seed cotton yield and fibre quality of cotton (Gossypium hirsutum L.) cultivar. The Journal of Cotton Science. 2011;15:243250.

3. Idem NUA. Cotton production in Nigeria. Kaduna; Baraka Press and Publication Ltd.; 1999.

4. Adeniji OB. Constraints to improved cotton production in Katsina state, Nigeria. Journal of Applied Sciences. 2007;7:16421651.

5. Sattar M, Safdar ME, lqbal N, Hussain S, Waqar M, Ali MA, Ali A, Javed MA. Timing of nitrogen fertilizer application influences on seed cotton yield. International Journal of Advanced Science and Research. 2017; 2(1):6-9.

6. Bhati AS, Manpreet S. Effect of split application of nitrogen and potassium on yield, nutrient uptake and nutrient use efficiency in cotton. Annals of Plant and Soil Research. 2015;7(1):71-73.

7. Ali N. Review: Nitrogen Utilization Features in Cotton Crop. American Journal of Plant Sciences. 2015;6:987-1002.

8. Tisdale SL, Nelson WL, Beaton JD, Havlin $\mathrm{JL}$. Elements required in plant nutrition. In soil fertility and fertilizers. McMillan Publishing Co., NY; 1993.

9. Radin JW, Mauney JR. The nitrogen stress syndrome. In Mauney JR, Stewart JM (ed.). Cotton physiology. Cotton Foundation. Memphis. 1986;91-105.

10. Belay A, Classens AS, Wehner FC, Beer JD. Influence of residual manure on selected nutrient elements and microbial composition of soil under long-term crop rotation. South African Journal of Plant and Soil. 2001;18:1 - 6 .

11. Iren OB, Asawalam DO, Osodeke VE, John NM. Effects of animal manures and urea fertilizer as nitrogen sources for Amaranthus growth and Yield in a Rainforest Ultisol in Nigeria. World Journal of Applied Science and Technology (WOJAST). 2011;3(1):73-78.

12. Iren OB, Uwah ID, Ekpenyong VE. Response of fluted pumpkin (Telfairia occidentalis, hook f.) to different levels of poultry manure application in an U/tisol of Southeastern Nigeria. Journal of Organic Agriculture and Environment. 2015;3:514.

13. Adeli A, Shankle MW, Tewolde H, Sistani $K R$, Rowe DE. Nutrient dynamics from broiler litter applied to no-till cotton in an upland soil. Agronomy Journal. 2008;100(3):564-570.

14. Iren OB, Asawalam DO, Osodeke VE, John NM. Comparative effects of animal manures and urea fertilizer on soil properties in a rainforest Ultisol. Journal of Agricultural Research and Policies. 2012;6(2):51-56.

15. Taraba State Ministry of Land and Survey Dairy; 2012.

16. Udo EJ, Trenchard OI, Ogunwale JA, Ardeshir AO, Esu IE. Manual of soil, plant and water analysis. Lagos; Sibon Book Festac; 2009.

17. Dong Z, Li WJ, Xin C, Wei T, Eneji AE. Lint yield and nitrogen use efficiency of fieldgrown cotton varies with soil salinity and nitrogen application rate. Field Crop Research. 2011;138:63-70.

18. Dugji IY, Kamara AY, Kwari JD. Analyses of soil physico-chemical properties determining Striga hermonthica infestations and grain yield of maize (Zea mays L.) in Nigerian Guinea and Sudan savannas. Nigerian Journal of Weed Science. 2008;21:23-37.

19. Adaikwu AO, Ali A. Assessment of some soil quality in Benue State. Nigerian Journal of Soil Science. 2013;23(2):66-75.

20. Wapa JM, Ojeniyi SO, Kwari JD. Response of extra-early maize variety (Zea mays) to different organic manures in the drier sub-region of Northern Nigeria. Nigerian Journal of Soil Science. 2013;23(2):52-59.

21. Ano AO, Ubochi Cl. Neutralization of soil acidity by animal manures: Mechanism of reaction. African Journal of Biotechnology. 2007;6(4):364-368.

22. Nwachukwu OI, Nyong AE, Opara UD. Effect of manures and ash on soil properties, yield and nutrient uptake of Amaranthus in an Ultisol of South East Nigeria. Nigerian Journal of Soil Science. 2012;22(2):70-78.

23. Udoh DJ, Iren OB, Jonathan JE. Comparison of fish pond waste water with manures under garden egg in Nigeria. Environment and Natural Resources Research. 2016;6(3):58-64.

24. Udoh DJ, Iren OB. Evaluation of fish pond effluent as an organic fertilizer in comparison with poultry and pig manures in the cultivation of Pineapple (Ananas comosus). International Organization of Scientific Research - Journal of Agriculture 
and Veterinary Science (IOSR-JAVS). 2016;9(9):5-10.

25. El-Shazly WMO, El-Masri MF. A comparative study on the effect of some organic manures and mineral nitrogen fertilizer on the leaf chemical composition, growth, earliness and yield of cotton (Giza 89 cultivar). Minufiya Journal of Agricultural Research. 2002;27:1325-1348.

26. Mitchell CC, Tu S. Long-term evaluation of poultry litter as a source of nitrogen for cotton and corn. Agronomy Journal. 2005;97:399-407.

27. Islam MK, Khalequzzaman Hassan MK, Kaikobad M. Effect of organic and inorganic source of $\mathrm{N}$ on cotton yield. Annual Research Report 2014, Cotton Development Board, Ministry of Agriculture, Bangladesh. 2014;131-142.
28. Tewolde $\mathrm{H}$, Bushring $\mathrm{N}$, Adeli A, Sistani $\mathrm{KR}$, Rowe DE, Pratt RG. Cotton response to chicken litter in rotation with corn in clayey soil. Agronomy Journal. 2009;101:626-634.

29. Adeli A, Sistani KR, Rowe DE, Tewolde H. Effects of broiler litter on soybean (Glycine max L.) production and soil nitrogen and phosphorus concentrations. Agronomy Journal. 2005;97:314-321.

30. Tewolde H, Sistani KR, Rowe DE. Broiler litter as a micronutrient source for cotton: Concentrations in plant parts. Journal Environment Quality. 2005;34:1697-1706.

31. Gnanasekaran J, Padmavathi S. Influence of season on yield and yield components in cotton. International Journal of Current Agricultural Research. 2013;2(12):59-61.

(c) 2017 Iren and Aminu; This is an Open Access article distributed under the terms of the Creative Commons Attribution License (http://creativecommons.org/licenses/by/4.0), which permits unrestricted use, distribution, and reproduction in any medium, provided the original work is properly cited.

Peer-review history:

The peer review history for this paper can be accessed here: http://sciencedomain.org/review-history/19093 